\title{
The Historical Thar Desert of India
}

\author{
Manisha Choudhary
}

\author{
Assistant Professor, \\ Department of History, \\ University of Delhi, India
}

DOI: https://doi.org/10.36941/mjss-2021-0o29

\begin{abstract}
Desert was a 'no-go area' and the interactions with it were only to curb and contain the rebelling forces. This article is an attempt to understand the contours and history of Thar Desert of Rajasthan and to explore the features that have kept the various desert states (Jodhpur, Jaisalmer, Barmer, Bikaner etc.) and their populace sustaining in this region throughout the ages, even when this region had scarce water resources and intense desert with huge and extensive dunes. Through political control the dynasts kept the social organisation intact which ensured regular incomes for their respective dynasties. Through the participation of various social actors this dry and hot desert evolved as a massive trade emporium. The intense trade activities of Thar Desert kept the imperial centres intact in this agriculturally devoid zone. In the harsh environmental conditions, limited means, resources and the objects, the settlers of this desert were able to create a huge economy that sustained effectively. The economy build by them not only allowed the foundation and formation of the states, it also ensured their continuation and expansion over the centuries. The continuity of the Rajput states in the Thar Desert is sufficient indicators of the fact that this desert was nourishing all of them efficiently.
\end{abstract}

Keywords: Thar Desert, Marwar, Jaipur, Mughal, Khaldun.

\section{Introduction}

'Rajasthan is the collective and classical denomination of that portion of India which is "the abode of Rajput princes". In the familiar dialect of these countries it is termed Rajwara,...more refined Raethana, corrupted to Rajputana, the common designation amongst the British to denote the Rajput principalities...'(Tod 1920:1). This representation of Rajasthan in $19^{\text {th }}$ century was due to the political dominance of Rajputs. In the last few decades, this concept has been overhauled in light of diverse researches. Large variety of research has pushed the region of our study to the stature of a concept and 'an idea' (Schomer, et al 2001). This research article is an attempt to understand the historical aspects of Thar Desert and its environment that has been highlighted so often by the travellers, state officials and inhabitants. The aim of this paper is to explore the un-attempted historical encounters of the Thar Desert that will help to understand that Thar Deserts was never devoid of any social and economic activities.

'Rajasthan' and 'Rajputana' was first used in the 19th century by Col. Tod, a political agent to Mewar state. This was done to distinguish this region as per its political authorities, i.e. different Rajput clans. Rajputana signified 'the country of the Rajputs' (Rajputana 1908:1). The territorial extent 
of Rajasthan was between 'the valley of the Indus on the west and Bundelkhand on the east; to the north, the sandy tracts (south of the Sutlej) termed Jangaldesh; and Vindhya mountains to the south' (Tod 1920:1), prior to the rise of Mandu and Ahmedabad with capitals at Malwa and Gujarat respectively. The administrative extent of the Imperial Rajputana included eighteen native states and two chief-ships (Rajputana 1908:1). As per the imperial administration, this state was an irregular rhombus with the boundary lines of the states of Bikaner, Jaisalmer, Banswara and Dholpur. The districts of Ajmer and Merwara (Tod:12) were also part of the its territorial circle. Placing the state in context of the geographical territory, it was bounded by Sindh on west, Bhawalpur defined its northwestern boundary and Punjab limited the north and north-east territories. The eastern frontier was adjoining the borders of Oudh and Agra. These territorial frontiers reflect the impact of Mughal administrative distribution till the beginning of 2 oth century. The states of Jaisalmer, Jodhpur (Marwar) and Bikaner formed a homogenous group in the west and north. Shekhawati along with Alwar (erstwhile Macheri) formed the north-eastern boundary. Jaipur, Dholpur, Karauli, Bundi, Kotah, Jhalawar and Bharatpur formed the eastern and south-eastern frontier. Sirohi marked the south-west and Pratapgarh, Banswara, Dungarpur and Udaipur formed the southern extent of state. The district of Ajmer-Merwara and Kishangarh state formed the centre. Even today, these boundaries are at work for various purposes. Aforementioned details indicate that the territories of state have not shifted much since the 2oth century. Most of the states in Rajputana were more or less, autonomous in their political operations, however, the imperial masters continued to surveillance and supervise. Thus, it is important to note that term-'Rajputana' doesn't hold any political or cultural sanctity. It was a cunning introduction by Tod to appease the Rajputs, in order to ensure his comfortable stay as a political agent, who was interested in writing a detailed description and history of the region.

\section{The Geographical Extent}

For understanding the state's territorial extent, it is important to take stock of its natural boundaries. Aravalli is the oldest mountain range of India. Since ancient times, the extensive branches of Aravalli are shaping and conducing the identity of this region. Accordingly, 'about three-fifth of Rajputana lie north-west of this line, leaving two-fifth on the south-east...Mount Abu are close to the southwestern extremity...while its north-eastern end may be said to terminate near Khetri in the Shekhawati country'(Rajputana 1908:2). Here, the Aravalli ranges have marked the state into two clear divisions, north-west and south-east. Thus, this demarcation is the starting point for this work to define the frontiers of Thar. The north-west is dry, arid, unproductive and ill watered area, but gradually towards the north-east the mere desert improves a bit from being purely sandy into a comparatively fertile and habitable land. The territory of Rajasthan was classified into eight categories and interestingly, 'the Indian desert to the valley of the Indus' (Tod 1920:2) was put on eighth rank. Tod shall be appreciated for noticing this landmass because until then it was largely ignored. Later, Adam's contributed significantly to understand the social and environmental history of the north-western states (Adams 1899).

The south-east of Aravalli contains higher and more fertile regions, starting near Mount Abu and then busting out in three directions: eastern, south-eastern and into northern frontier of Gujarat and Malwa. River Chambal and its tributaries made the southern and south-eastern Rajasthan a cultivable and inhabitable area. Most of this zone is covered with rocks, sand and volcanic rock formations thus making it uncultivable. This situation (availability of water and non-availability of the cultivable land) makes it 'Wet Thar', and this appears a parallel to the 'Dry Thar', which lies in the north-western frontier of the state. Thus, territories on both the sides of Aravalli are Thar. This article is an effort to explore the 'Dry Thar' and its ecological, social, and cultural environs. It is a maiden voyage to look into the environmental aspects of the Thar Desert, its biotic and a-biotic components that evolved its economy, society and culture.

The Dry Thar, is "the "great desert" forming the whole of the Rajputana-Sindh frontier, extends from the edge of Rann of Cutch beyond the Luni river northward; and between it and what has been 
called as the 'little desert' on the east is a zone of less absolutely sterile country, consisting of rocky land cut up by limestone ridges, which to some degree protect it from the desert sands. The 'little desert' runs up from the Luni river between Jaisalmer and Jodhpur into the northern wastes...It is covered by sand-hills, shaped generally in long straight ridges, which seldom meet, but run in parallel lines, separated by short and fairly regular intervals, resembling the ripple-marks on a sea-shore upon a magnified scale. Some of these ridges might be two miles long, varying from 50 to $100 \mathrm{ft}$, or even more, in height; their sides are covered by water and at a distance they look like substantial low hills. Their summits are blown into wave-like curves by the action of the periodical westerly winds; they are sparsely clothed with stunted shrubs and tufts of coarse grass in the dry season, while the light rains cover them with vegetation. The villages within the desert, though always known by local names, cannot be reckoned as fixed habitations, for their performance depends entirely on the supply of water in the wells, which is constantly falling or turning brackish; and as soon as the water gives out, the village must shift. A little water is collected in tanks or pools, which become dry before the stress of heat begins, and in places there are long marshes impregnated with salt. This is the character, with more or less variation, of the whole north and north-west of Rajputana. The cultivation everywhere is poor and precarious, though certain parts have better soil than others, and some tracts are comparatively productive. Along the base of Aravalli range from Abu north-east towards Ajmer, the submontane region, lying immediately under the abrupt northern slopes and absorbing their drainage, is well cultivated, where it is not covered by jungle, up to the Luni; but north-west of this river the surface streams are mere rain gutters, the water in the wells sinks lower and lower, and the cultivation becomes more patchy and poorer as the scanty loam shades off into the shady waste. As the Aravalli approach Ajmer, the continuous chain breaks up into separate hills and sets of hills. Here is the midland country of Rajputana, with the city of Ajmer standing among the scattered hills upon the highest level of an open table-land, which separates east towards Jaipur and slopes by degrees to all points of the compass. From Ajmer the Arvalli trend (turns) north-eastward, never reuniting in a chain but still serving a divide roughly, though less distinctly, the sandy country on the north and the west from the kindlier soil on the south and east' (Rajputana, 1908:2-3).

Generally, the social and political economy of regions is guided by the environment and availability of the natural resources, which in long run leads to the emergence of specific cultural setups. Primarily, to understand any region, exploration of its geographical aspects is essential. Further, one needs to see the environmental factors that are regular and have become permanent features for a mean-time. Over it, essential is to mark and record the natural spurts that occurred occasionally.

The inspiration to explore a desert is well defined by Ibn Khaldun, who wrote extensively about the desert of Egypt. He has motivated many scholars to explore hot and arid areas. Ironically, his work has been used seminally and has yet not received its due, as a remarkable historical work on 'the contributions of desert in the life of the societies' and the way desert has 'influenced and aspired', the societies and the communities to march ahead in 'the process for the formation' of dynasty, and setting-up the cities. The desert of Cairo was his inspiration for penning the voluminous history of Egypt. 'He retired in Desert (Rabit Abu Madyan) busying himself in solitude with study and reading' (Enan 1941:49). He was no exception for aspiring solitude. Historically, alienations and solitudes always had immense effect on the individuals. The Mamluk (slave-soldier) of the medieval ages are most notable examples to understand the effects of alienation. And the way it has set and revolved the discourse of time is worth consideration. The finest Mamluks were the ones who had suffered the twin effect of 'natal alienation and social death' (Patterson 1982). This particular social-experience refined them to become the finest slaves, who exclusively reserved their loyalties and honesty for their respective masters and their projects. Mostly they were the flag-bearers of the capitals. Khaldun also suffered alienation and distance from his family but he was never subjected to social death. He chose solitude over social life for compiling his experiences. The credit for creative creation (The Muqaddimah) is due to solitude. This outcome of solitude in desert clearly indicates that the deserts are very much contained frames of life and substantial ecological module. A rich exercise of thinking and writing the great text-The Muqaddimah became possible due to the amazing contributions of a 
desert and the happening retirement secured by author, in its sands!

In this article contours of Thar Desert of Rajasthan will be explored that have kept the various desert states (Jodhpur, Jaisalmer, Barmer, Jaipur and Bikaner) and their populace sustaining in this region since time immemorial. It will also locate the various means, resources and the objects that were available to the inhabitants, and will lens how in these limited resources they created an economy and sustained it, effectively. The creation of local social and environmental economy not only allowed the foundation and formation of many states, apparently it also ensured their continuation and expansion over many centuries. The constant efforts of various Rajput states for continuing their territorial and political control in the Thar Desert are indicators to the fact that the dense, dry and hot-Thar desert was nourishing all of them efficiently. Thar Desert became an important engrain for their survival, and continuity in it was made possible through organs of the state. The absence of permanent efforts to move out of this desert by the inhabitants, the royals, and their establishments clearly indicates that the Great Indian Desert was not inimical to the nomads, sedentary societies, royal authorizes, cities and civilizations. They were constantly developing and prospering in this environmentally adverse region. However, the limited availability of water resources made the inhabitants to divert their efforts from agricultural operations towards the creative expressions (like art and handicraft), inorder to make a worthy living. The temporary migrations were featured regularly to sustain the pastoral wealth which constitutes a major share of economy.

In the light of various sources, it can be asserted that Thar Desert was a space for many activities even after the harsh natural conditions. Till date, majority of the works around Thar are limited to the social and economic history of the states that were territorially and historically fixed in the Thar Desert. It has permitted a limited exploration of the revenue records, administrative systems and cultural set-ups. A complete absence of researches to see all these states as blooms of the Thar Desert is disheartening. And, somewhere it indicates that the researchers have adopted a 'notinterested in attempting un-approachable natural conditions' approach. Historian never exerted to understand the causes for continued struggle amongst the desert kingdoms. In terms of the environment, seminal works exist on the water-harvesting and conservation that too only in context of the ruling dynasties.

Here, Thar is approached in line with the historical time frames and geographical zones to explore the analysable features, and processes of particular age and an identified region. Similar approach will be followed to get an insight into its environmental factors and their considerations, as they were guiding and motiving the spirit and zeal of the inhabiting souls. Gradually, the political associations emerged as per the environment, and both jointly guided the discourse of history.

\section{The Region of Death}

On entering Hindustan, Babur experienced the Garmsir (hot region) for first time. For the precolonial dynasties, the desert was a 'no-go area' (Guha 1999:4) and interactions with it were only to curb and contain the rebelling forces. The Sanskrit and Persian literature are rich in metaphors, drawn from the nature. Mughal sources use ample comparatives from nature to convey meanings of political situations, like a traitor was called a scorpion without self-control in sting (Fazal 2010:576). Similarly, the natural terrains were interpreted as per ecological conditions, and sense drawn from their surroundings. In Akbarnama, the desert always stands as an equal of destruction, bewilderment, waste, wilderness, a place of illusions, purposeless wandering, ignorance, ruin, madness, error, defeat, annihilation, downfall, calamity, folly, imitation, darkness, savages, exile, failure, asceticism, etc. Contrary to it, the cities were considered, an equivalent of the inquiry, prosperity, civilization and truth. The Mughal court historian has always treated desert as a destination/destiny which 'rebels will meet' (Fazal 2010:434). The rebels were called 'desert vagabond' (Fazal 2010:459) and, defeat was a 'desert of failure' (Fazal 2010:466). Rana Pratap was called 'desert vagabond' due to rebellion.

Interesting both historians (Ibn Khaldun and Abul Fazal), clearly hold opposite views on the 
desert. The former considered desert a base of any civilization whereas for later it represented ignorance, error, ruins, etc. 'Civilization may be either desert (Bedouin) civilization as found in outlying regions and mountains, in hamlets (near suitable) pastures in waste regions, and on the fringes of sandy deserts' (Khaldun 1980:10-11). Observing these two different opinions about the same natural terrain, the effect exerted by the natural surrounding and environment on the souls becomes evident. Generally, the influences and effects of the desert over the souls and their psychology are immense. Similarly, the approaches of both the historians were directly linked with the proximity and distance enjoyed and experienced by them. Fazal experienced fertile and agriculturally rich zones that were served well by rivers and their multiple tributaries. So, for him a positive imagination about desert was impossible. Whereas, Khladun lived and worked in the desert of Egypt, therefore, for him the desert was a centre of civilization. This creative approach for desert was naturally unattainable for Fazal. Thus, the affinity with desert allowed one to appreciate it extensively and the distinctness pushed the other to mark it, a region-devoid of any intellectual activity. Similarly, the desert of Thar was a 'Marusthali' (region of death) for Col. Tod.

To base his theory of sociology, Khaldun spoke about the science of the subject and explained 'the nature of society, the necessity for it and how it varies according to the climate, how it is affected by changes of weather hot, cold and temperate zones, the effect of atmosphere on the character, colour, and condition of men and...the geography of the world'(Enan:126). Further, 'to understand the political development...it was necessary to include in the study all aspects of social life and to understand...it was needful to take into account the physical factors...widening the scope of history, and the broadening of the historian's task'(Enan:186). Thus, it is evident that the deserts were also shaping the great philosophers and were no hindrance in the inventions that were aspired by the sciences. On similar lines, this study is an attempted to explore the contributions made by Thar Desert to the Indian subcontinent over the centuries.

Khaldun tried to understand the geography of the globe. For it he drew a map on basis of the information found in the Book of Rogers and the Geography (Ptolemy). He notes, 'Information about the cultivated part and its boundaries and about the cities, towns, mountains, rivers, waste areas, and sandy deserts...extensive narrations and information like locations of the seas, sand, deserts, oceans and their geographical marks' (Khaldun 1980:91-98). Interestingly, the Eastern India (49), Western India (40) and the desert (46) are components in the key to the Map designed by Al-Khazani, a leading scholar of geography (Khaldun 1980:96-8). He further notes 'Civilization exists only on the islands in (the Indian Ocean) which are numerous and said to number up to one thousand. (Civilization also exists) on the southern coast of the Indian Ocean, the southernmost limit of the cultivated part of the earth, as also on its northern coast' (Khaldun 1980:103). This clearly indicates to the activities and cultural developments that were churning in the Indian Ocean.

Arab geographers collected similar kind of data about the north-western frontier, its desert and its wanders, with whom they encountered around the frontier towns of Hind (Wink 1999:165). Ibn Hauqal said, 'the Mids wandered "along the banks of Mihran" from the boundary of Muslim kingdom of Multan to sea, and in desert between Makran and Qamuhul (Famhal), "the frontier town of Hind"' (Wink 1999:165). Idrisi locates the Mids outside the desert and confirmed their wandering nature. Wink has established that the interstitial pastures along the Indus and the desert were zones of high nomadic activities along the north-western frontier (Wink 1999:166). As per Tarikh-i-Sind (160o AD), when the authority of Masud (son of Mahmud) was rejected by the people of distant regions, 'the men of Sumara assembled in the neighbourhood of Thari (Thar) and raised a name Sumara to masnad who had passed a long time as the head of the Sumara tribe' (Daudpota 1938:60). In 1810-11, two parties were dispatched for conducting surveys, 'one to the Indus, the other to the desert south of the Sutlej' (Tod 1920:5). He further mentions about 'the deserts of Dhat, Umrasumra (it joins in Jaisalmer) and many of the states of Rajasthan' (Tod 1920:6). Thus, it is evident that Thar was an inhabited desert with nomadism as its core. 


\section{Floral Marked Territories}

Later, with the formation of the Rajput states in desert the flora were used to mark the territories of states. An envoy accompanying Col. Tod to Marwar defined the capital (Marwar) of desert-'Ak ra jhonpra, phog ri var, Bajra ri roti, motham (motha) hari dal, dekho ho raja, teri Marwar (Huts of the ak, barriers of thorns, bread of maize, lentils of the vigna (vetch), behold raja, your Marwar!)'(Tod 1920 ii:811). Another version of it propounded as 'Bajri ka sogra, montha ke daar (daal), Akre ke jhupri, phogan ke baar, dekhi raja Man Singh teri Marwar! (The bread of bajra, curry of green pulses, the hut of akra, the peripheral wall of phog, oh! Raja Man Singh, have seen your Marwar!)' (Adam 1889:97). So far, these are the best possible expressions about the geographical features of desert state and its cultural life. The envoy also requested Tod for marking the territories between Mewar and Marwar State as per the geographical features and availability of flora. To make his case he said, 'even on principle Godwar is ours, for nature has marked our limit by stronger features than mountains. Observe, as you advance, and you will find to the further limit of the province every shrub and flower common to Mewar; pass that limit but a few yards, and they are lost: Anwal (aonla-Phyllanthus emblica), anwal Mewar; Bawal (babul-Acacia arabica), bawal Marwar. Wherever the anwal puts forth its yellow blossoms, the land is of right ours...let them enjoy their stunted babul, their karil (Capparis aphylla) and the ak (Calotropis gigantea); but give us back our sacred pipal (Ficus religiosa), and anwal of the border' (Tod 1920 ii:811). Tods confirmation of floral distinction came as, 'the transition is beyond credence marked: cross but a shallow brook, and you leave all that is magnificent in vegetation; the papal, bar (Ficus bengalensis) and that species of the mimosa resembling the cypress, peculiar to Godwar, are exchanged for the prickly shrubs, as the wild caper, jawas (Hedysarum alhagi) and many others, more useful than ornamental, on which the camel browses' (Tod 1920 ii:811).

The western desert was also called 'Thal ka Tiba', which literally means the sand ridges of the desert. Luni river marks the 'extensive plain of ever shifting sand, termed in Hindu geography Marusthali, corrupted to Marwar' (Tod 1920:19). The Thal ka Tiba is basically a corrupt version of Thul $k a$ Tiba, where the word 'Thul' signifies 'sand' and 'Tiba' represents 'dune'. Similarly, the Marusthali is also a land which takes you near death due to its harsh dry weather conditions and absence of the potable water resources. Both these terms are still in use. The locals rarely address this western desert of India as Thar. For them, this vast desert is only Dharti dhora ri, ei par dev raman ne aawa; ei ro jas nar-nari gava... (its the land of undulating sand dunes, the gods incarnate to inhabit on this land; man and women sing its praise...) and definitely not marusthali.

In the nineteenth century, a British officer stated that the descendants of Yadu tribe were pushed out from Punjab by the King of Ghizni and they fled into the Great Indian Desert and 'built a fortress in the desert, which they called Tanot and made it their capital in AD 731' (Malleson 1875:118). A historian asserts 'both the archaeological finds and certain climatologically features, however indicate that Ghaggar did not carry water as a river after the middle of the sixth century AD...the correct climate tradition about this region is also recorded in the Vamana-Purana which was compiled in Kurukshetra. There were several holy places which were once associated with big ponds, felt helpless against the advancing dunes of sand' (Jain 2016:573). He has not used the word 'Thar' for the desert, but his vivid descriptions of the locations confirms about the desert that was expanding in the region of Rajasthan due to drying up of river Ghaggar. Geographers propose, 'there are archaeological evidence that the region was better watered as recently as the 8th century AD and the flow in Ghaggar did not cease until 1790 AD' (Gupta and Prakash 1975:11). Thus, the first instance for the expansion of the desert towards the eastern frontier can be located around the 6th century AD. All the specific territorial demarcations and geographical descriptions indicate to vibrancy held by the Great Indian Desert even after the harsh environmental conditions which now reflects in memories and histories.

Abul Fazal has narrated the surroundings of Thar Desert, its location and the difficulties faced by the imperial forces in and around this desert (Fazal 2010:371-5). He also highlighted the importance and requirement of water and food in the desert, as their shortages was experienced by 
the imperial forces. Further, he called the Central Asian desert as $\mathrm{Cul}$ and its people were referred as culi (Fazal 2010:412). However, he refrained from putting any such label on the inhabitants of the Thar Desert. Perhaps, it was due to the absence of any uniformity amongst the nomadic groups who were living and traversing in it. Or, might be this desistance was due to the non-acquaintance with the region, its people and their cultural diversities. The desistance from labelling could also be an act of diplomacy, as the Mughal Empire under the reign of Akbar was trying to expand its horizons in order to gain legitimacy over the extensive territories of Hindustan. The aim of these multidirectional expansions (pushed by the Mughal centre in the sixteenth century) was clearly economic as extraction of more and more revenue was aimed for imagining and building a grand empire and extending patronization.

Defining the contours of desert Tod has done a more confirming job-'From the north bank of the Luni to the South, and the Shaikhavat frontier to the east, the sandy region commences. Bikaner, Jodhpur, Jaisalmer are all sandy plains, increasing in volume as you proceed westward...Jaisalmer is everywhere encircled by desert; and that portion round the Capital might not be improperly termed as oasis, in which wheat, barley and even rice are produced. Though all these regions collectively bear the term Marustahli, or 'region of Death', the restrictive definition applies to a part only that under the dominion of the Rathor race. From Balotra on the Luni, throughout the whole of Dhat and Umrasumra, the western portion of Jaisalmer and a broad strip between the southern limits of Daudputra and Bikaner, there is real solitude and desolation. But from the Sutlej to the Rann, a space of five thousand miles of longitudinal distance, and varying in breath from fifty to one hundred miles, numerous oases are found, where the shepherds from the valley of Indus and Thal pasture their flocks. The spring of water in these places have various appellations, tar, par, rar, dar, all expressive of the element, round which assemble the Rajars, Sodhas, Mangalias and Sahariyas, inhabiting the desert...the valley of Indus and eastward of the stream, the termination of the sand ridges of the desert...of this eastern portion of the valley, which forms the western boundary of desert. A traveller proceeding from Khichi or flats of Sindh to the east, sees the line of the desert distinctly marked, with its elevated tibas or sand ridges...these sand-hills are of considerable elevation, and may be considered the limit of the inundation of the 'sweet river', the Mitha Maran, a scythic or Tatar name for river, and by which alone the Indus is known, from the Panjnad to the ocean' (Tod 1920:21-2).

With all these illustrations it can be said that the extent of the sand hills (dhoras) in Thar was and is limited to the regions of Barmer, Jaisalmer, Jodhpur, Ganganagar and Bikaner with a little depletion in the sand dunes while moving towards Sikar, Churu, Jhunjhnu, and Nagaur. Beyond it the effect of the desert was felt till the north-western extent of the Aravalli hills. Specifically, Indus formed the north-western frontier of the Thar and the Aravalli ranges limited the south-eastern extent of it. All the above discussions indicate that the Thar Desert was an extensive area with scanty water supplies and sparse production of food-grains, however, its inhabitants were surviving due to their own managements-skills (water-harvesting etc.). Ironically, no source acknowledges their efforts, technology and skills.

Till sixteenth century the ruling houses of Thar were not docile to the imperial capitals (Delhi, or Agra). This was due to the impact exerted by environment of Thar on the psychology of the inhabitants. As aridity limited the scope of conducive agricultural conditions, the lack of water resources made it undesirable for the agriculture-based societies. Thus, nomadic culture evolved as the life-saver in which pastoral communities travelled long-distance with large number of cattle in search of food and water.

\section{Mughals and Colonial Officials}

The abundance of agricultural revenue that was available in the Ganga-Yamuna Doab formed major share of the states (Delhi sultanate, Mughal Empire and John Company) incomes. Thus, the Thar was not aspired for agricultural income. The expeditions, penetrations, and expansions in desert were primarily to control the trade-routes as they were connecting-links to Central Asian cities and 
markets ahead. The control over trade-networks was crucial as the routes and the dunes of Thar were the main lands for import of horses and other luxury items and breeding. Apparently, massive trade marts and emporiums (Pali, Jaislamer, Sojat and Merta) developed in Indian desert. Even after the extension of imperial authority in these territories, the central (core) state never directly came out to manage this region. For organizing various activities in the region, the state employed the native Rais and Ranas, as the intermediaries (representatives) of the imperial power. And as an administrative unit, Thar was left under their autonomous guidance. Till the end of the 16th century as watan-jagir various ruling dynasties had autonomy and control over their respective regions. The interference of Mughal state in the desert region was limited. In order to gain a direct control over the passages into western India, desert region and its trade routes, Nagaur, Ajmer and Jalor were made outposts of the Mughal empire. Plethora of evidences indicate that the Mughal state was constantly working to keep Nagaur safe and under control. The Nagaur jagir was of strategic importance, therefore, was always assigned to the most trustworthy officials. During the early years of Akbar's reign, Nagaur was jagir of Bairam Khan. Later, it was allotted to Munim Khan and many other officials whom the emperor trusted. When Bairam Khan rose in rebellion, to exert imperial control, 'Nagor and its territory were given to M. Shrifuddin Hussain' (Fazal 2010 (ii):155). After reconciliatory round, when Bairam Khan escaped from Agra, Akbar ordered-'the word-traversing standards should advance from Delhi and establish themselves at Nagor, so that Bairam Khan might not be able to plant his foot in that region' (Fazal 2010 (ii):152). As an loyal of emperor, Sharafuddin Husain got charge of Nagaur during Bairam Khan's rebellion. His credentials of 'real worthlessness and insubstantiality became' manifested in 1562 when he escaped from the capital of Agra for 'Ajmer and Nagor which were his jagirs' (Fazal 2010 (ii):303). On getting information of his escape, Akbar ordered, 'that one of his trusty servants should be appointed to the province of Nagor' (Fazal 2010 (ii):303). In furtherance of emperor's orders, Husain Quli Beg was immediately promoted and title of Khan was conferred upon him. Consequently, Sharafuddin Husain's jagir was assigned to him and he was sent-off to take charge of Nagaur (Fazal 2010 (ii):304). The significance of Nagaur, Jalore, Sojat, Jaisalmer, Ajmer, Bikaner and Pali was due to their strategic geographical locations and immense trade that passed and exchanged through these centres. The imperial efforts were exclusively oriented to control the economic resources, secure economic benefits and regulate the political churnings. The non-interference of the imperial state with the social life and cultural set-ups of the desert was due to the elements of nomadism.

Even during peace times, nearly all the medieval states kept their forces active. Albeit, the Mughals were making many exceptions from the medieval kingdoms but in this matter they also didn't extend any privilege to their standing army. This was to keep the soldiers on-practice and inform. For practising war-skills, constant drills were organised in the forest-areas as they represented foe, wilderness and package full of surprises. These specifications made forests fit 'perfect grounds/fields' to refine and sharpen the skills of war, to train soldiers and arenas to display the acts of bravery. The constant engagement of Akbar in forests (hunting), during en-route journeys are remarkable examples of the army training. Jahangir was also very regular with his hunting expeditions. The control and power exerted over the animal was always defined as a synonym of controlling the rebellions and the acts to curb the wilderness (Choudhary 2018). The absence of forest cover and the limited presence of the sporting activities in the Indian desert limited the exchanges of imperial forces with this region. Though, hunting expeditions were organised in the regions of Ajmer, Nagaur etc. but those were limited to shooting of nilgais, gazelles, deer, some small animals and variety of birds.

The following narrative helps to understand the texture of desert and negotiations set-in (or employed) by the groups transverse-ing through it. 'Al-Mas'udi also mentioned that one of the Himyar kings after Afriqus, Dhul-Adh'ar, who lived in the time of Solomon, raided the Maghrib (a desert of North Africa) and forced it into submission. Something similar is mentioned by alMas'udi...He is said to have reached the Sand River in the Maghrib and to have been unable to find passage through it because of the great mass of sand. Therefore, he returned.... Soldiers traveling in 
regions other than their own have to requisition grain and livestock and to plunder the countries they pass through. As a rule, such a procedure does not yield enough food and fodder. On the other hand, if they attempted to take along enough provisions from their own region, they would not have enough animals for transportation. So, their whole line of march necessarily takes them through regions they must take possession of and force into submission in order to obtain provisions from them. Again, it would be at most unlikely and impossible assumption that such an army could pass through all those nations without disturbing them, obtaining its provisions by peaceful negotiation....Although Maghrib has often been crossed and its roads have been explored by travelers and raiders at all times and in every direction' (Khaldun 1980:62-3). This narrative defines the problems and the managements required to be put-in place by the traders and raiders before settingout in any intense desert. For the Mughals, the Desert of Thar was a region to be left with the inhabitants only. This saintly attitude was due to the harsh weather conditions of the Thar. Therefore, the desert was left with the Rajput dynasts who established kingdoms in midst of Thar. As mentioned above, the desert of Thar for the Mughals was the synonym of decline and a region for ending, and concluding various unpleasant events and ill-assorted personas of the state (Fazal 2010 (ii):371-72). The confusions, challenges, and illusions posed by desert were used for burying various unaccepted events, and disapproving and deifying personalities of the state. The execution and expulsion of Bairam Khan is the glaring example of it. Thus, the desert accommodated and justified the professional approach of the imperial state!

The Thar Desert holds a very different approach towards the life. With the introduction of Islam in this region, this approach got altered to another degree. Arrival of Moinuddin Chistti around the end of the 12th century also caused a direct disparity. Here onwards, Ajmer got directly connected with Delhi and the exchanges between both the regions became regular. The occasional interactions of Sultanate with Ajmer were limited to collection of revenue. At times the political victory of Islam was commemorated. Adhai din ka Jhopra is a living example of it. Today, it is a popular historical site mainly for those who perform pilgrimage to dargah of Mohinuddin Chistti, as it stands close to the grave of saint. Hardly any intriguing mind reaches it. The regular visitors to this site are enthusiast love-birds, children searching cricket pitches, and grazing goats and cows. Except minor violent engagements and altercations, these constant share-holders manage their respective spaces without any real struggles. Beyond Ajmer Sultanates never tried explore the Thar. Few efforts were made to control the regions of southern Rajasthan for conquering the invincible forts of Ranthambor and Chittor, as both were crucial locations to penetrate in the central India and gain access to the western coast. Later, with expansion of the 'religious frontier' (Eaton 1993) of Islam, the Chisttis established one shrine at Nagaur and Chistti Hamiduddin Nagauri was declared its leader. Both Ajmer and Nagaur became leading centres of Sufism. The Thar Desert was not oblivious to this cultural expansion. The exploitation of the natural surroundings is an obvious character of humans irrespective of sectarian affiliations. With new introductions, the interaction with Thar changed for political and religious reasons. The Sufi centres of Ajmer and Nagaur emerged as popular centre of religious and educational activities, thus attracted politically ambitious personalities, pilgrims, aspiring Islamic theologicians and jurists. These interactions accelerated the movements of humans and animals in Thar which accelerated the political interactions also. Open struggles between the centre and the dynasties of Thar were rare. The desert states acted as autonomous bodies even after accepting Mughal sovereignty. Their special association with empire was certified through grant of twin land-assignments, i.e. watan-jagir and tankhwa-jagir. This arrangement helped the Mughals to control Thar better, without getting-in the troubles posed by its sandy terrains. The imperial supervision helped in exploring the sources that were either under/unexplored.

The desert of Thar forms a rectangular territory and the noteworthy cities of Rajasthan-Barmer, Jodhpur, Jaisalmer and Bikaner lie in vast dunes. Hanumangarh, Ganganagar Jaipur, Ajmer, Sikar, Fatehpur, and Churu are the chief cities in its arid-zone. Amongst the above mentioned cities/states, the foundation of Jaisalmer (Tanot) dates earliest. Since the thikana of Sikar was found in the late 18th century, it can be counted as last. The most significant of these states was Jodhpur (Marwar). Its 
foundation was laid down by Rao Jodha in VS 1515/1459 AD (Powlett 1874:i). As per Colonel Malleson, the Bhatis of Jaisalmer were the descendants of the Yadu tribe and they formed their capital in the Great Indian Desert by building a fortress called Tanot in AD 731 (Malleson 1875:118). The Amber kingdom of Kachwahha Rajputs was a small territory. Fortune arrived to them only after forming alliance with the Mughals in 1564 AD. 'Jaisalmer, Gagraun, Bundi, the abodes of the Bhatti, the Khichi and the Har, with many of minor importance, suffered all the horrors of assault..., though destined again to raise their heads. The Rathors of Marwar and the Kachhwahas of Amber were yet in a state of insignificance: the former were slowly creeping into notice as the vassals of the Pariharas, while the latter could scarcely withstand the attack of the original Mina population' (Tod:312). The Bikaner kingdom was found by Rao Bika. Bika left Jodhpur in $1465 \mathrm{AD}$ and laid down the foundation of Bikaner city in 1489 AD (Powlett:1-3). Most of these clans assert their claims for respective regions around the late eight century. So, it can be asserted that the foundation of all dynasties in the Thar Desert began around eighth century. Initially, they were managing small fiefs. By the mid/end of sixteenth century, all these clans were able to secure their respective kingdoms.

The rise of Amber-kingdom to prominence after forming matrimonial-alliance with the Mughals (Fazal:241-43 and Prasad:8) continued to attain eminence. Looking at the sporadic rise of the Amber-kingdom, states of Jodhpur (Zigler 1976:219-250, 1976:127-153 and 1978:215-250), Jaisalmer (year 1570) and Bikaner (Fazal:518) also formed matrimonial-alliance with the Mughals, to secure their fortunes.

It would be interesting to know why, when and how these ruling houses landed in the desert. The earliest ruling house was of Tanot (Jaisalmer). They arrived in this area due to the expulsion encountered by them at the hands of Gahzni in the eighth century. The settlement of Rathors in the Thar was 'the splendor of this monarchy...weakened by its contest with the Chauhans of Delhi, it fell a pray to the invaders, and how, in sambat 1268 (AD 1212), eighteen years subsequent to the overthrow of Kanauj, Seoji and Sait Ram, grandsons of its last monarch, abandoned the land of their birth, and with two hundred retainers, the wreck of their vassalage, journeyed westward to the desert with the intent, according to some of the chronicles, of making a pilgrimage to the shrine of Dwarka, but according to others and with more probability, to carve their fortunes in fresh fields unscathed by the luxuries in which they had been tried, and proud in their poverty and sole heritage, the glory of Kanauj' (Powlett:i). The Rathors under the leadership of Seoji reached the wilds of Marwar and nearly after two hundred years of this migration, the capital of Marwar was established by Rao Jodha in 1459 AD. 'Only tribes held together by group feeling can live in the desert' (Khaldun:170). Similarly, being attached by the feeling of clan and kin the rajputs gradually evolved a culture which slowly penetrated in the region and allowed them to settle, survive and prosper. They didn't stay in the places where they were not owned or not allowed to flourish at a regular pace. The continuity of Rathors in Thar for nearly two hundred years led to the foundation of Marwar. The political economy of community feeling and their interaction came out loud with the formation of the Marwar state (Jodhpur).

\section{Conclusion}

Many dynasties disintegrated and collapsed due to possible absence of an effective leader, and the community affiliations. In Thar, the scarcity of resources, lack of defence, and constant exposure to harsh climate were sufficient reasons for the communities to come together and aspire jointly. 'The restraining influence among Bedouin tribes comes from their shaykhs...The hamlets of the Bedouins are defended against outside enemies by a tribal militia composed of noble youths of the tribe who are known for their courage. Their defence and protection are successful only if they are a closelyknit group of common descent. This strengthens and their stamina makes them feared, since everybody's affection for his family and his group is more important (than anything else).' (Khaldun:170-71). Thus, in the deserts, it is rare or impossible to see a state not based on kinship and clan-associations. 
Thus, the Thar Desert was never devoid of the human activities and over the centuries, being a base of multi-layered exchanges, it has allowed many cultures to flourish in its undulating womb. The archaeological evidences located around the course of river Ghaggar are solid proofs to establish this contention of the Thar Desert from the upper Paleolithic age onwards. Its contributions to the subcontinent have been significant that made the survival and subsistence all the beings, living-in, and moving through this sand ocean since time unmemorable. To churn-out connecting-links a gradual exploration of evidences and the geographical setting, along with the collections of folklores will pave for larger deliberations.

\section{References}

Abd Ar Rahman-bin Muhammed Ibn Khaldun, (1980). The Muqaddimah: An Introduction to History, (trans.) Franz Rosenthal. 3. Vols., Princeton New Jersey: Bollingen Foundation.

Abul Fazal, Akbarnama, (2010), 2. Vols., (trans.) H. Beveridge. Delhi: Low Price publication.

Adams, Lt. Col. A., 1899. The Western Rajputana States: A Medico-topographic and General Account of Marwar, Sirohi, Jaisalmer, London: Junior Army and Navy Stores Ltd.

Choudhary, Manisha, (2018). Setting the Game of Ferocity and Innocence: Hunts of Jahangir, American Research Journal of History and Culture, IV, pp. 1-18.

Daudpota, U. M. (ed.), (1938). Tarikh-i-Sind, Poona.

Eaton, Richard M., (1993). The Rise of Islam and Bengal frontier: 1204-1760, Berkeley: University of California Press.

Geertz, Clifford, (2006). 'History and Anthropology', in Historiography: Critical Concepts in Historical Studies, Robert M Burns (ed.), vol. IV (Culture). London and New York: Routledge.

Guha, Sumit, (1999). Environment and Ethnicity in India 1200-1991, Cambridge Studies in India History and Society, vol. 4, Cambridge: Cambridge University Press.

Gupta, Rajkumar and Ishwar Prakash (eds.), (1975). Environmental Analysis of the Thar Desert, Dehradun: English Book Depot.

Imperial Gazetteer of India, Provincial Series: Rajputana, (1908). Calcutta: Superintendent of Government Printing, (Reprint 2007: Jodhpur, 2007).

Jain, K. C., (2016). Ancient Cities and Towns of Rajasthan, Jodhpur: Rajasthani Granthagaar.

Karine Schomer, Joan L. Erdman, Deryck O. Lodrick \& Lloyd I. Rudolph (eds.), (2001). The Idea of Rajasthan: Explorations in Regional Identity, 2. Vols. Delhi: Manohar.

Lorenz, Chris, (1998). 'Historical Knowledge and Historical Reality: A Plea for Internal Realism', in History and Theory; Contemporary Readings, Brian Fay, Philip Pomper and Richard T. Vann (eds.), Malden Mass: Blackwell.

Malleson, Col. G. B., (1875). An Historical Sketch of The Native States of India: In Subsidiary Alliance with the British Government, London: Longmans Green and Co.

McCrindle, J.W., (1885). Ancient India: As described by Ptolemy, London.

Muhammad Abdullah Enan, (1941). Ibn Khaldun: His Life and Works, Lahore: Shaikh Muhammad Ashraf.

Patterson, O., (1982). Slavery and Social death: A Comparative Study, Cambridge: Cambridge University Press.

Prasad, R. N., (1966). Raja Man Singh of Amber, Calcutta: The World Press private Ltd.

Powlett, Captain P. W., (1874). Gazetteer of the Bikaner State, Introduction, Calcutta: Office of Superintendent of Government Printing.

Tod, Colonel James, (1920). Annals and Antiquities of Rajasthan, William Crooke (ed.), 3. Vols. London: Oxford University Press.

Wink, Andre, (1999). Al-Hind: The Making of the Indo-Islamic World, Early Medieval India and the Expansion of Islam $7^{\text {th }}-11^{\text {th }}$ Centuries, vol.1, New Delhi: Oxford University Press.

Zigler, Norman P., (1976). 'The Seventeenth Century Chronicles of Marvara: A Study in the Evolution and use of oral Traditions in Western India', in History in Africa, vol. 3, (1976), pp. 127-153.

Zigler, Norman P., (1976). 'Marwari Historical Chronicles: Sources for the Social and Cultural History of Rajasthan', in The Indian Economic and Social History Review, 13(2), pp. 219-250.

Zigler, Norman P., (1978). 'Some Notes on Rajput Loyalties during the Mughal Period', in J. F. Richards, (ed.) Kingship and Authority in South Asia, South Asia Studies, Maidson, pp. 215-250. 